\title{
Self-Efficacy Ibu Dalam Memberikan ASI Eksklusif di Institusi Pendidikan Kesehatan Yogyakarta
}

\author{
Hesti Widuri',*, Wiwin Lismidiati², Sumarni DW ${ }^{3}$ \\ ${ }^{1}$ Mahasiswa Magister Keperawatan, Fakultas Kedokteran, Universitas Gadjah Mada, \\ Jl. Farmako Sekip Utara Yogyakarta, 55281, Yogyakarta, Indonesia \\ ${ }^{2}$ Program Studi Ilmu Keperawatan Fakultas Kedokteran, Universitas Gadjah Mada \\ Jl. Farmako Sekip Utara Yogyakarta, 55281, Yogyakarta, Indonesia \\ ${ }^{3}$ Departemen Psikiatri Fakultas Kedokteram, Universitas Gadjah Mada \\ *) E-mail: hestiwiduri2511@gmail.com
}

Diterima: Februari 2018, diterbitkan: Agustus 2018

\begin{abstract}
ABSTRAK
Latar Belakang: Self efficacy ibu menyusui merupakan salah satu kunci keberhasilan pemberian ASI. Banyaknya tempat kerja yang dirasakan oleh ibu bekerja belum menyediakan ruang laktasi dan fasilitas serta kebijakan untuk ibu bekerja yang menyusui Institusi Pendidikan Kesehatan di wilayah Kotamadya Yogyakarta. Kemungkinan kendala lainnya adalah jauhnya jarak tempat kerja dan waktu cuti bagi ibu bekerja. Tujuan: Mengekplorasi self-efficacy menyusui pada ibu bekerja. Metode: Desain penelitian yang digunakan adalah kualitatif dengan pendekatan fenomenologi. Populasi dalam penelitian ini adalah ibu-ibu yang memiliki anak usia 0-6 bulan yang bekerja di Institusi Kesehatan di Wilayah Kotamadya Yogyakarta. Jumlah sample sebanyak 6 informan inti dan 1 informan pendukung, dengan tehnik purposive sampling. Instrument dalam penelitian ini adalah peneliti sendiri, alat perekam, alat tulis, pedoman wawancara mendalam, dan lembar observasi, dengan waktu wawancara dilakukan selama 25-30 menit, yang dilaksanakan antara bulan OktoberNovember 2016. Data dianalisis dengan tahapan teori . Hasil: Ditemukan lima tema yaitu adanya harapan dan motivasi ibu dalam memberikan ASI eksklusif, perlunya persiapan \& ketrampilan yang dimiliki ibu, kesulitan fisik yang dialami ibu, beban psikologis yang dialami ibu, keterbatasan waktu \& fasilitas yang dirasakan ibu bekerja dalam memberikan ASI eksklusif. Kesimpulan: Ibu bekerja dalam memberikan ASI eksklusif, mengalami hal-hal yang menyenangkan dan hal-hal yang kurang menyenangkan. Hal menyenangkan yang mereka rasakan adalah adanya harapan, motivasi, memiliki persiapan, dan ketrampilan. Sedangkan hal-hal yang kurang menyenangkan adalah adanya masalah fisik, kondisi psikologis, minimalnya support sistem, kurangnya fasilitas, dan keterbatasan waktu bersama bayinya.
\end{abstract}

Kata Kunci: Self-Efficacy, ibu bekerja, ASI eksklusif

\section{Mother's Self-Efficacy in Exclusive Breastfeeding at Health Education Institution in Yogyakarta ABSTRACT}

Background: Self efficacy of breastfeeding mothers is one of the keys to the success of breastfeeding. Working mothers still thinks that many workplaces do not provide lactation rooms and facilities as well as policies for working mothers who breastfeed at the Health Education Institutions in Yogyakarta Municipality. Another possible obstacle is distance of workplace and leave time for working mothers. Objective: To explore self-efficacy of breastfeeding in working mothers. Methods: The research is qualitative with phenomenological approach. The population was mothers who had children aged 0-6 months who worked at the Health Institutions in Yogyakarta Municipality. The number of samples was 6 key informants and 1 supporting informant, whom were taken using with purposive sampling. The instruments of the research included researcher, recording devices, stationery, in-depth interview guidelines, and observation sheets, with the interview duration of 25-30 minutes, which was held between October-November 2016. Data were analyzed using Creswell's theory of stages. Results: Five themes were found, namely expectation and motivation of mothers in exclusive breastfeeding, 
need for preparation and skills possessed by mothers, physical difficulties experienced by mothers, psychological burden experienced by mothers, limited time and facilities felt by mothers working in exclusive breastfeeding. Conclusion: Working mothers in exclusive breastfeeding had both pleasant and unpleasant experiences. The pleasant experiences include hope, motivation, preparation, and skills. Meanwhile, unpleasant experiences include physical problems, psychological conditions, minimum system support, lack of facilities, and limited time with the baby.

Keywords: Self-Efficacy, working mothers, exclusive breastfeeding

\section{PENDAHULUAN}

Mengacu pada target program tahun 2014 sebesar $80 \%$, secara nasional cakupan pemberian Air Susu Ibu (ASI) eksklusif belum mencapai target, yaitu masih sebesar $52,3 \%$. Berdasarkan data dari Profil Kesehatan Indonesia (2014), hanya satu provinsi yang telah mencapai target yaitu Provinsi Nusa Tenggara Barat sebesar $84,7 \%$ dan Provinsi Daerah Istimewa Yogyakarta urutan ketujuh sebesar $70,8 \%$. Menurut laporan Dinas Kesehatan Provinsi Daerah Istimewa Yogyakarta Tahun 2012 pada tahun 2008 cakupan ASI eksklusif di Provinsi DIY mencapai $49,5 \%$ pada tahun 2011, mengalami peningkatan pada tahun 2012 menjadi $58,2 \%, 66,08 \%$ pada tahun 2013 , dan $70,79 \%$ pada tahun 2014. Dari $70,79 \%$ tersebut wilayah Kota Yogyakarta sebesar $54,92 \%$, Kabupaten Bantul sebesar 71,55\%, Kabupaten Kulonprogo sebesar $74,27 \%$, Kabupaten Gunungkidul sebesar 59,46\%, dan Kabupaten Sleman sebesar 81,20\%.

Keberhasilan dalam memberikan ASI eksklusif pada ibu bekerja sangat bergantung dari lingkungan terutama dukungan suami, keluarga lainnya, rekan kerja, atasan, dan komitmen sehingga ibu dengan nyaman memberikan ASI eksklusif sambil tetap bekerja. Memberikan ASI eksklusif bukan hanya masalah ibu saja namun juga merupakan masalah bagi keluarga dan masyarakat (Ikatan Dokter Anak Indonesia/ IDAI, 2010).

Banyaknya tempat kerja yang belum menyediakan ruang laktasi dan fasilitas serta kebijakan atau aturan untuk ibu bekerja yang menyusui juga masih dirasakan oleh beberapa ibu bekerja yang bekerja di beberapa Institusi Pendidikan Kesehatan di wilayah Kotamadya Yogyakarta.

Masa cuti hamil hanya 3 bulan saja, namun bukan berarti ibu bekerja menghentikan pemberian ASI eksklusif. Dengan memiliki pengetahuan yang benar tentang menyusui, perlengkapan memerah ASI, dan dukungan lingkungan kerja, ibu bekerja dapat tetap memberikan ASI eksklusif selama bekerja (Roesli, 2000). Bagi ibu bekerja sebaiknya dapat mengatur waktunya untuk dapat menyusui atau memerah ASI diantara kesibukan kerjanya. Hasil penelitian Muaningsih (2013) menjelaskan, salah satu tentang aspek yang memengaruhi keberhasilan menyusui adalah keyakinan ibu (self-efficacy). Self efficacy ibu menyusui dalam memberikan ASI pada bayi merupakan salah satu kunci keberhasilan pemberian ASI.

\section{METODE}

Penelitian kualitatif dengan pendekatan fenomenologi, untuk menjelaskan gambaran mendalam tentang self efficacy ibu bekerja dalam memberikan ASI eksklusif pada bayinya berdasarkan sudut pandang individu tersebut. Enam orang partisipan inti yang bersedia ikut serta dalam penelitian ini adalah ibu bekerja yang masih memiliki bayi usia 0-6 bulan dan masih menyusuinya dan satu partisipan pendukung. Pengumpulan data dilakukan dengan wawancara mendalam. Observasi lapangan pada bulan OktoberNovember 2016. Triangulasi dilakukan kepada rekan kerja dari informan inti dan observasi lapangan. Analisis data menggunakan 
metode (2009/2014) dengan tahapan setelah membuat transkrip wawancara dan membaca kembali, kemudian menentukan makna, mengatur makna, menggabungkan hasil tema-tema, merumuskan deskripsi, dan validasi deskripsi. ljin etik penelitian diberikan oleh Fakultas Kedokteran Universitas Gadjah Mada pada tanggal 26 September 2016.

\section{HASIL}

Partisipan dalam penelitian ini berjumlah 6 orang ibu bekerja yang masih menyusui bayinya. Karakteristik partisipan tersebut disajikan dalam Tabel 1. Dari Tabel 1 dapat dilihat bahwa rentang usia partisipan adalah 26-34 tahun, dua partisipan pasca sarjana dan empat partisipan berpendidikan sarjana. Semua partisipan masih dalam proses memberikan ASI eksklusif dan telah selesai menjalani cuti melahirkan. Pada penelitian ini ditemukan lima tema antara lain: 1) Adanya harapan dan motivasi ibu dalam memberikan ASI eksklusif, 2) Perlunya persiapan dan ketrampilan yang dimiliki ibu bekerja dalam proses menyusui, 3) Kesulitan fisik yang dialami ibu bekerja dalam menyusui, 4) Beban psikologis yang dialami ibu bekerja dalam memberikan ASI, 5) Keterbatasan waktu dan fasilitas yang dirasakan ibu bekerja dalam proses memberikan ASI eksklusif. Pembentukan tema keterbatasan waktu dan fasilitas yang dirasakan ibu bekerja dalam proses memberikan ASI eksklusif seperti nampak pada Gambar 1.

Ibu bekerja yang memiliki harapan kuat untuk memberikan ASI eksklusif untuk anaknya telah menyadari bahwa untuk mewujudkan harapan tersebut diperlukan komitmen sejak awal, rencana sejak hamil untuk memberikan ASI eksklusif, sejak hamil memiliki keyakinan dan kewajiban dalam memberikan ASI eksklusif. Berikut ini pernyataan Partisipan: "memang komit saya dari awal anak kedua harus ASI eksklusif" (P1).

Ibu bekerja yang memiliki motivasi untuk memberikan ASI eksklusif pada bayinya memiliki keyakinan kuat bahwa ibu mampu memberikan ASI eksklusif pada bayinya. Berikut ini adalah pernyataan partisipan:

"...saya masih optimis saya bisa (memberikan ASI) dengan jumlah produksi yang sekarang..." (P5).

Untuk dapat memberikan ASI eksklusif pada bayinya meskipun ibu bekerja, ibu perlu persiapan sejak awal, seperti mengatur strategi cara menyusui bayinya. Berikut ini pernyataan partisipan:

"...saya stok (ASI) dulu banyak-banyak...". P5

Melatih cara bayi minum ASI sebagai salah satu ketrampilan yang diperlukan ibu untuk dapat mewujudkan pemberian ASI eksklusif pada bayinya, walaupun ibu tetap bekerja. Hal tersebut dapat dilihat dari ungapan partisipan:

"Ketika saya latih untuk minum tidak langsung dari puting itu cepet banget jadi sebenarnya kan memang yang lebih bagus pakai sendok ya bu...". (P2)

Hasil wawancara dengan partisipan menyimpulkan bahwa kondisi fisik yang mereka rasakan diantaranya adalah ibu belum membiasakan bayi minum ASI perahan, masalah puting susu, keterbatasan waktu memerah, dan cara memberikan ASI disesuaikan dengan jarak ibu dan anak. Berikut ini adalah pernyataan partisipan:

"...karena puting tenggelam saya terpaksa sampai sekarangpun masih mengunakan sambungan puting...". (P3)

Kondisi psikologis ibu bekerja yang dialami partisipan karena banyaknya beban kerja mempengaruhi produksi ASI, dan perlu rileks. Berikut ini ungkapan partisipan:

"Yang penting tidak stress dan tidak capek. Karena itu sangat berpengaruh...". (P3) 
Partisipan mengatakan merasakan minimalnya support sistem yang diperlukan seperti halnya yang mereka rasakan adalah sulit mencari pengasuh, dan ibu sudah mulai bekerja. Ibu sudah mulai bekerja menjadi salah satu beban psikologis yang dialami ibu yang dirasakan sebagai minimalnya support sistem bagi mereka. Berikut ini ungkapan partisipan:

"Cemasnya bukan karena asinya tapi karena justru cari yang tukang momong, karena memang sangat sulit". (P1)

Beberapa pendukung untuk proses ASI eksklusif adalah adanya fasilitas proses menyusui baik tempat maupun privasinya, dan lemari es atau pendingin untuk ASI perahan, namun tidak semua institusi memiliki fasilitas pendukung tersebut untuk proses ASI eksklusif. Berikut ini adalah ungkapan partisipan:

"...di sini ruangan untuk memerah tidak ada kemudian untuk menyimpan asinya juga belum ada , jadi kan eee kalo baru pertama mungkin kebingungan yah...". (P2)

Masa cuti yang kurang efektif, belum mendapatkan hak cuti, dan pemberian waktu cuti lama di sebelum melahirkan yang dirasakan oleh ibu sebagai keterbatasan waktu bersama bayi yang mereka rasakan. Berikut ini ungkapan dari partisipan:

"Seminggu pertama, karena kebiasaan waktu saya cuti itu kan anak saya menyusui langsung". (P3)

Tabel 1. Karakteristik Partisipan

\begin{tabular}{|c|c|c|c|c|c|c|c|}
\hline Partisipan & Umur & $\begin{array}{c}\text { Pendidikan } \\
\text { Terakhir }\end{array}$ & $\begin{array}{l}\text { Tempat } \\
\text { Bekerja }\end{array}$ & $\begin{array}{c}\text { Anak } \\
\text { ke }\end{array}$ & $\begin{array}{l}\text { Umur } \\
\text { Bayi }\end{array}$ & $\begin{array}{c}\text { Kondisi } \\
\text { Bayi }\end{array}$ & $\begin{array}{c}\text { Pengalaman } \\
\text { Ekslusif }\end{array}$ \\
\hline P1 & $30 \mathrm{Th}$ & S2 & $\mathrm{KH}$ & 2 & $6 \mathrm{bl}$ & $\begin{array}{c}\text { Masih } \\
\text { menyusu }\end{array}$ & Pertama kali \\
\hline P2 & $34 \mathrm{Th}$ & S2 & $\mathrm{KH}$ & 3 & 5,6 bl & $\begin{array}{l}\text { Masih } \\
\text { menyusu }\end{array}$ & Ketiga kali \\
\hline P3 & $26 \mathrm{Th}$ & S1 & Poltekes & 1 & $4 \mathrm{bl}$ & $\begin{array}{c}\text { Masih } \\
\text { menyusu }\end{array}$ & Pertama kali \\
\hline P4 & $27 \mathrm{Th}$ & S1 & Poltekes & 1 & $\begin{array}{c}5 \mathrm{bl}, 17 \\
\mathrm{hr}\end{array}$ & $\begin{array}{l}\text { Masih } \\
\text { menyusu }\end{array}$ & Pertama kali \\
\hline P5 & $33 \mathrm{Th}$ & S1 & Bethesda & 1 & $3 \mathrm{bl}$ & $\begin{array}{l}\text { Masih } \\
\text { menyusu }\end{array}$ & Pertama kali \\
\hline P6 & $26 \mathrm{Th}$ & S1 & Bethesda & 1 & $6 \mathrm{bl}$ & $\begin{array}{c}\text { Masih } \\
\text { menyusu }\end{array}$ & Pertama kali \\
\hline & \multicolumn{2}{|c|}{ Kategori } & & & & Tema & \\
\hline
\end{tabular}

\begin{tabular}{|l|l|}
\hline $\begin{array}{l}\text { Kurangnya fasilitas yang } \\
\text { diperlukan }\end{array}$ & $\begin{array}{l}\text { Keterbatasan waktu dan fasilitas } \\
\text { yang dirasakan ibu bekerja } \\
\text { dalam proses memberikan ASI } \\
\text { eksklusif }\end{array}$ \\
$\begin{array}{l}\text { Keterbatasan waktu bersama } \\
\text { bavi }\end{array}$
\end{tabular}

Gambar 1. Pembentukan tema Keterbatasan waktu dan fasilitas yang dirasakan ibu bekerja dalam proses memberikan ASI eksklusif 


\section{DISKUSI}

Tema pertama dalam penelitian ini menggambarkan bahwa ibu bekerja yang memiliki harapan kuat untuk memberikan ASI eksklusif untuk anaknya telah menyadari bahwa untuk mewujudkan harapan tersebut diperlukan komitmen sejak awal, rencana sejak hamil untuk memberikan ASI ekskusif, sejak hamil memiliki keyakinan dan kewajiban dalam memberikan ASI eksklusif. Hal tersebut sejalan dengan penelitian lain, yaitu perjuangan dan usaha ekstra, dukungan positif dari keluarga dan sosial serta pengalaman sebelumnya tentang menyusui meningkatkan komitmen, motivasi dan efikasi diri wanita Aceh dalam memberikan ASI eksklusif (Fitri, 2015). Seperti yang telah dijelaskan dalam teori, bahwa aspek emosional dari menyusui adalah adanya hubungan anak dan ibu, sebagai komitmen bagi ibu bahwa ASI tidak dapat digantikan untuk bayinya, dan tidak ingin kehilangan kesempatan karena menyusui mampu meningkatkan hubungan yang hangat, mesra, dan aman penuh dengan cinta antara ibu dan anaknya (Proverawati \& Rahmawati,2010).

Pada penelitian ini didapatkan hasil bahwa ibu bekerja yang memiliki motivasi untuk memberikan ASI eksklusif pada bayinya memiliki keyakinan kuat bahwa ibu mampu memberikan ASI eksklusif pada bayinya. Penelitian tersebut seperti hasil penelitian Basri (2009), seorang ibu bekerja yang termotivasi secara identified regulation secara sadar menilai dan memutuskan bahwa memberikan ASI eksklusif merupakan suatu perilaku yang penting bagi dirinya. Dalam teori diuraikan bahwa, motivasi terkuat dari banyak wanita untuk menyusui sendiri bayinya adalah kesehatan bayinya, bukan kepuasan dirinya sendiri, dan mereka terus menyusui bayinya meskipun tidak menikmatinya. Ibu yang optimis, percaya diri bahwa ia bisa menyusui, dan meyakini bahwa
ASI adalah sumber nutrisi terbaik untuk bayi, lebih mungkin untuk menyusui lebih lama Lowdermilk, Perry, \& Cashion (2010/2013).

Tema kedua dalam penelitian ini menggambarkan bahwa untuk dapat memberikan ASI eksklusif pada bayinya meskipun ibu bekerja, ibu perlu persiapan sejak awal, seperti mengatur strategi cara menyusui bayinya. Hasil penelitian lain yang mirip dengan penelitian tersebut menjelaskan bahwa ibu bekerja memiliki strategi tertentu untuk mencapai keberhasilan dalam memberikan ASI eksklusif (Anggraeni, Nurdiati, \& Padmawati. 2015). Hasil penelitian ini juga menggambarkan bahwa melatih cara bayi minum ASI sebagai salah satu ketrampilan yang diperlukan ibu untuk dapat mewujudkan pemberian ASI eksklusif pada bayinya, walaupun ibu tetap bekerja. Sesuai dengan hasil penelitian lainnya yang menjelaskan bahwa teknik menyusui dikaitkan dengan peningkatan keyakinan dalam menyusui. Hal tersebut menunjukkan bahwa ibu yang mengetahui teknik yang benar ketika mereka masih menyusui bayinya, mereka dapat terus menyusui secara eksklusif karena meningkatkan kepercayaan diri (Ingram, et al. 2015).

Tema ketiga dalam penelitian ini menggambarkan bahwa, kondisi fisik yang mereka rasakan diantaranya adalah ibu belum membiasakan bayi minum ASI perahan, masalah puting susu, keterbatasan waktu memerah, dan cara memberikan ASI disesuaikan dengan jarak ibu dan anak. Hal tersebut juga dapat dilihat dari penelitian lainnya (Choiriyah, Hapsari, \& Lismidiati, 2015) yang menjelaskan bahwa, salah satu keluhan puting terbenam, membuat keluarga menganjurkan ibu menghentikan menyusui bayinya dan memberikan MPASI.

Tema keempat dalam penelitian ini didapatkan dari hasil wawancara dengan partisipan yaitu, Kondisi psikologis ibu 
bekerja yang dialami partisipan dalam penelitian ini, karena banyaknya beban kerja mempengaruhi produksi ASI, dan perlunya rileks. Sejalan dengan penelitian lainnya (Nguyen et al., 2011) yang menjelaskan bahwa, nenek bayi mempunyai pengaruh yang besar dalam praktik menyusui bagi ibu dan bayinya. Suami dan keluarga merupakan sumber dukungan fisik dan emosional yang utama. Minimalnya support sistem yang diperlukan oleh partisipan dalam penelitian ini adalah sulit mencari pengasuh dan ibu sudah mulai bekerja. Sejalan dengan hasil penelitian Lunberg \& Thu (2012) yang mengatakan bahwa kesulitan terbesar dari menyusui adalah pada saat ibu kembali bekerja, bahkan saat bayi belum berusia 6 bulan. Keberhasilan ibu bekerja dalam memberikan ASI eksklusif, dapat diwujudkan dengan memiliki strategi tertentu untuk mencapai keberhasilan dalam memberikan ASI eksklusif.

Tema kelima dalam penelitian ini didapatkan hasil bahwa, beberapa ibu bekerja menyatakan bahwa di tempatnya bekerja belum ada sarana dan prasarana yang dibutuhkan untuk melakukan pemerahan ASI dan penyimpanan hasil perahannya. Hasil penelitian Ismail et al. (2012) yang sejalan dengan penelitin ini menjelaskan bahwa, ibu bekerja tidak dapat memberikan ASI eksklusif karena tidak tersedia sarana dan prasarana menyusui, jam kerja yang tidak fleksibel dan jarak rumah yang jauh. Dari hasil penelitian ini menggambarkan bahwa, masa cuti yang kurang efektif, belum mendapatkan hak cuti, dan pemberian waktu cuti lama di sebelum melahirkan yang dirasakan oleh ibu sebagai keterbatasan waktu bersama bayi, namun ibu menanamkan keyakinan pada dirinya untuk tetap mampu memberikan ASI eksklusif. Hasil penelitian lainnya yang sejalan dengan penelitian Anggraeni, Nurdiati, \& Padmawati (2015) menyimpulkan salah satu strategi bagi ibu bekerja untuk mencapai keberhasilan dalam memberikan ASI eksklusif adalah adanya kebijakan menyusui yang perlu diberikan ibu di tempat kerja. Diharapkan pemerintah memberikan kebijakan dengan mewajibkan kepada semua institusi agar menyediakan sarana prasarana untuk mendukung program ASI eksklusif pada ibu yang bekerja, sehingga ibu memiliki kepercayaan diri untuk tetap memberikan ASI ekslusif selama mereka telah mulai bekerja kembali.

\section{SIMPULAN}

Peneliti menginterpretasikan hasil penelitian ini bahwa adanya harapan dan motivasi ibu, adanya persiapan dan ketrampilan yang dimiliki ibu mampu memberian kepercayaan diri pada ibu bekerja dalam menyusui eksklusif pada bayinya, meskipun melalui kesulitan fisik, memiliki beban psikologis, mengalami keterbatasan waktu dan fasilitas yang dirasakan ibu bekerja dalam proses memberikan ASI eksklusif.

Ibu bekerja dalam memberikan ASI eksklusif, mengalami hal-hal yang menyenangkan dan hal-hal yang kurang menyenangkan. Hal menyenangkan yang mereka rasakan adalah adanya harapan, motivasi, memiliki persiapan, dan ketrampilan. Sedangkan hal-hal yang kurang menyenangkan adalah adanya masalah fisik, kondisi psikologis, minimalnya support sistem, kurangnya fasilitas, dan keterbatasan waktu bersama bayinya.

\section{UCAPAN TERIMA KASIH}

Penulis mengucapkan terima kasih kepada dosen pembimbing dan penguji, Ketua Program Studi, beserta Institusi Pendidikan Kesehatan Wilayah Kotamadya Yogyakarta dan partisipan yang telah berpartisipasi dalam penelitian ini. 


\section{DAFTAR PUSTAKA}

Anggraeni, I. A., Nurdiati, D. S., \& Padmawati, R. S. (2015). Keberhasilan ibu bekerja memberikan ASI eksklusif. Jurnal Gizi dan Dietetik Indoenesia, 3(2): 69-76.

Basri, H. (2009). Pengaruh sosial budaya masyarakat terhadap tindakan pemberian ASI eksklusif di wilayah kerja Puskesmas Kecamatan Rumbai Pesisir Kota Pekanbaru (Tesis). Program Studi Administrasi dan Kebijakan Kesehatan Konsentrasi Administrasi dan Kebijakan Kesehatan Sekolah Pascasarjana Universitas Sumatera Utara, Medan, Indonesia.

Choiriyah, M., Hapsari, E. D., Lismidiati, W. (2015). Tradisi dan lingkungan sosial memengaruhi dukungan menyusui pada bayi berat badan lahir rendah di Kota Malang. Kesmas: Jurnal Kesehatan Masyarakat Nasional, 10(1): 37-43.

Creswell, J. W. (2014). Research design qualitative, quantitative, and mixed methods approaches (Third Edition). (Alih Bahasa: Achmad Fawaid). Yogyakarta: Pustaka Pelajar. (Buku asli terbit 2009).

Dinas Kesehatan Provinsi Daerah Istimewa Yogyakarta. (2012). Laporan cakupan ASI Eksklusif nasional. Dokumen tidak dipublikasikan.

Fitri, A. (2015). Pengalaman pemberian ASI eksklusif pada wanita Aceh (tesis). Program Studi Magister Keperawatan, Fakultas Kedokteran, Universitas Gadjah Mada, Yogyakarta, Indonesia.

Ikatan Dokter Anak Indonesia (IDAI). (2010). Indonesia menyusui. Jakarta: Badan Penerbit IDAI.

Ingram, J., Debbie J., Marion, C., Hazel, T. (2015). The development of a new breastfeeding assessment tool and the relationship wih breasfeeding selfefficacy. Midwifery, 31: 132-137.
Ismail, T. A. T., Sulaiman, Z., Jalil, R., Muda, W. M. W. (2012). Breastmilk expression among formally employed women in urban and rural Malaysia: A qualitative study. International Breastfeeding Journal, 7(11): 1-8.

Lowdermilk, D., Perry, S., \& Cashion, K. (2013). Maternity Nursing. (Alih Bahasa: Sidartha, F \& Tania, A.). Jakarta: Salemba Medika. (Buku asli diterbitkan 2010).

Lundberg, P. C., \& Thu, T. T. N. (2012). Breastfeeding attitudes and practices among Vietnamese Mothers in Ho Chi Minh City. Midwifery, 28: 252-257.

Muaningsih. (2013). Studi komparasi antara breastfeeding self-efficacy pada ibu menyusui di RSSIB dengan non RSSIB dan faktor yang mempengaruhinya (tesis). Program Magister Keperawatan Universitas Indonesia, Jakarta, Indonesia.

Nguyen, P. H., Menon, P., Ruel, M., Hajeebhoy, N. (2011). A situasional review of infant and young child feeding practices and inteventions in Vietnam. Asia Pac. J. Clin. Nutr, 20: 359-374.

Profil Kesehatan Indonesia 2014. Retrieved from www.depkes.go.id/resources/ donwload/pusdatin/profil-kesehatan

Proverawati, A. \& Rahmawati, E. (2010). Kapita selekta ASI \& menyusui. Yogyakarta: Nuha Medika.

Roesli, U. (2000). Mengenal ASI eksklusif. Jakarta: Trubus Agriwidya. 